\title{
Functional characterization of HIV-1 Tat exon-1 variants from North India and their implications on HIV-1 transactivation and TAR interaction
}

\author{
Larance Ronsard $^{1,2^{*}}$, VG Ramachandran², Akhil C Banerjea ${ }^{1}$ \\ From 2nd International Science Symposium on HIV and Infectious Diseases (HIV SCIENCE 2014) \\ Chennai, India. 30 January - 1 February 2014
}

\section{Background}

HIV-1 virus is a rapidly evolving virus due to genetic variability through its rapid replication, mutation and recombination potential which is a major hurdle in vaccine development. One of the effective ways to modulate HIV-1 infection is to target viral proteins; among the viral proteins, Tat plays a major role in HIV-1 pathogenesis. It activates viral gene expression through TAR interaction. The aim of this study was to characterize genetic and functional variants of Tat exon-1 from HIV-1 patients from North India.

\section{Methods}

DNA was isolated from PBMCs and Tat exon-1 was PCR amplified with specific primers followed by cloning, sequencing and sequence analysis using bioinformatics tools for predicting subtypes, recombination events, conservation of domains and phosphorylation sites. Unique Tat exon-1 variants were functionally characterized for LTR transactivation, TAR interaction and cell death.

\section{Results}

Genetic analysis of Tat exon-1 variants revealed 90\% subtype $\mathrm{C}$ and $10 \% \mathrm{~B} / \mathrm{C}$ recombinants, and the functional characterization showed varying levels of LTR transactivation, TAR interaction and cell death. A single mutation (S46F) in Tat exon-1 variants showed enhanced LTR transactivation through strong interaction with TAR.

\section{Conclusion}

Possible role of Tat exon-1 variants in shaping the current HIV-1 epidemic in North India is discernible. Natural

\footnotetext{
*Correspondence: laraphds@gmail.com

${ }^{1}$ Virology lab - II, National Institute of Immunology, New Delhi, India

Full list of author information is available at the end of the article
}

substitutions across the conserved functional domains were observed. There is evidence for the emergence of $\mathrm{B} / \mathrm{C}$ recombinants within Tat exon-1. The impact of genetic variations in Tat exon-1 on its pivotal functions is apparent. These are likely to have implications for HIV-1 pathogenesis and strategies of vaccine formulations.

\section{Authors' details}

'Virology lab - II, National Institute of Immunology, New Delhi, India. 2Department of Microbiology, UCMS and GTB Hospital, New Delhi, India.

Published: 27 May 2014

doi:10.1186/1471-2334-14-S3-P81

Cite this article as: Ronsard et al:. Functional characterization of HIV-1 Tat exon-1 variants from North India and their implications on HIV-1 transactivation and TAR interaction. BMC Infectious Diseases 2014 14(Suppl 3):P81.

\section{Submit your next manuscript to BioMed Central and take full advantage of: \\ - Convenient online submission \\ - Thorough peer review \\ - No space constraints or color figure charges \\ - Immediate publication on acceptance \\ - Inclusion in PubMed, CAS, Scopus and Google Scholar \\ - Research which is freely available for redistribution

